Carl-Johan Rundgren är sedan 2003 doktorand i naturvetenskapernas didaktik vid Forskarskolan i Naturvetenskapernas och Teknikens Didaktik (FontD) med placering vid Linköpings universitet. Han har tidigare arbetat som gymnasielärare i naturvetenskapliga ämnen och är också verksam som lärarutbildare vid Linköpings universitet.

CARL-JOHAN RUNDGREN

Nationella Forskarskolan i Naturvetenskapernas och Teknikens Didaktik / Linköpings universitet, Sverige

carru@isv.liu.se

\title{
Att börja tala 'biokemiska' \\ - Betydelsen av metaforer och hjälpord för meningsskapande kring proteiner
}

\begin{abstract}
This paper deals with the process of acquiring a subject-specific language. When confronted with the visual representations and scientific terms of molecular life science, students try to make meaning using the language they have access to and their prior experience. In this process students use a kind of intermediate language, with frequent use of metaphors. Some metaphors can be traced back to the teaching they have experienced, while some are spontaneous metaphors created by the students. They also make use of words that seemingly have no meaning, here referred to as helpwords. The results from this study indicate that spontaneous metaphors and helpwords are important in learning situations, especially in an abstract discipline such as molecular life science. This paper aims to give a preliminary theoretical description of the phenomenon of helpwords, based on an interview study of 20 students taking natural science courses in their upper secondary school education.
\end{abstract}

\section{INTRODUKTION}

Under senare år har flera författare fokuserat hur språket används för att skapa mening i det naturvetenskapliga klassrummet (Lemke, 1990; Mortimer \& Scott, 2003; Ogborn, Kress, Martins \& McGillicuddy, 1996; Rivard \& Straw, 2000; Sutton, 1995). Lemke (1990) hävdar att språket inte enbart ska ses som ett passivt medium genom vilket tankar uttrycks, utan att språket aktivt formar vår förmåga att observera, beskriva och jämföra. Att lära sig naturvetenskap kan enligt Lemke betraktas som att lära sig att delta i en kommunikativ praktik.

Den ryske litteraturvetaren Bakhtin (1986) har lyft fram skillnaderna i användning av språket mellan olika sociala verksamheter. Olika sfärer av verksamhet ger upphov till skilda sociala språk, vilka är oupplösligt förbundna med den praktik ur vilken de vuxit fram. Gee (2003) talar om olika semiotiska domäner, vilka använder olika modaliteter (tal, skriven text, gester, visuella representationer, artefakter o s v) för att kommunicera distinkta typer av mening. Han menar vidare att det är mycket svårt att skilja lärande av det språk som används inom ett område och lärande av ämnesinnehåll. Innehållet blir tillgängligt genom det områdesspecifika språkbruket och det områdesspecifika språkbruket får mening av innehållet (Gee, 2004).

När det gäller det sociala språk som brukas inom naturvetenskapen har man ofta framhållit dess rationella, abstrakta och kontextoberoende karaktär (t ex Bernstein, 1964). Frågan är dock om detta inte snarare beskriver ett vetenskapligt ideal än det naturvetenskapliga språk som talas pro- 
fessionellt eller inom utbildning. Goodwin $(1995,1996)$ har påvisat att det språk som talas av professionella naturvetare under daglig yrkesutövning är allt annat än kontextoberoende. En annan fråga är hur det naturvetenskapliga språk som används i klassrummet bör karaktäriseras. Ämnesspråket i den naturvetenskapliga undervisningen bygger med nödvändighet på ett naturvetenskapligt språkbruk, men skiljer sig från det språk som brukas inom vetenskapssamhället. Det finns en skillnad mellan det ämnesspråk som används av läraren och av eleverna, samtidigt som det ämnesspråk som läraren använder i klassrummet i hög grad bidrar till att forma elevernas ämnesspecifika språkbruk. En kanske förbisedd fråga är om rationalitet, abstraktion och oberoende av kontext är karaktäristiska drag för det språk som används i det naturvetenskapliga klassrummet.

Gee hävdar att skolundervisningen många gånger misslyckas med att förmedla meningsfull kunskap om sociala praktiker och att man fastnar på en nivå av texters bokstavliga betydelse. Orsaken till att ungdomar misslyckas i skolan är vanligen inte att de inte lär sig att förstå vad texter bokstavligen betyder, utan snarare att texterna aldrig blir meningsfulla, eftersom ungdomarna saknar erfarenhet av den sociala praktik som texterna refererar till (Gee, 2003, 2004).

I diskussionerna kring språkets betydelse i den naturvetenskapliga undervisningen kan man i huvudsak urskilja två tyngdpunkter för forskningsintresset. Antingen står de sociala, kommunikativa och kulturella aspekterna av ett vetenskapligt språk i fokus, eller också är det de kognitiva aspekterna av naturvetenskapen som står i fokus, och hur man kan förstå hur de lärande utifrån sitt sätt att använda språk tänker kring det naturvetenskapliga innehållet. Denna studie har målsättningen att ta hänsyn till bägge aspekter, med utgångspunkt från en uppfattning av lärande av innehåll och lärande av ämnesspråk som sammantvinnade, men inte helt identiska, processer. Till grund för artikeln ligger en intervjustudie av gymnasieelevers sätt att tolka visuella representationer av proteiner. Den empiriska undersökningen beskrivs mer uttömmande i Rundgren (2006). Artikeln utgör i första hand ett försök att teoretiskt beskriva de resultat som framkommit. Under avsnittet "Teoretisk bakgrund" följer en översikt över den litteratur som den teoretiska beskrivningen utgår från.

\section{FRÅGESTÄLLNINGAR}

- Vilka språkliga resurser använder gymnasieelever för att skapa mening kring visuella representationer av proteiner?

- Kan elever uttrycka en naturvetenskaplig förståelse med hjälp av icke-vetenskapliga termer?

\section{TEORETISK BAKGRUND}

\section{Meningsskapande}

Betydelsen av tidigare erfarenheter och kunskaper för möjligheten att ta till sig nya erfarenheter och ny kunskap har lyfts fram av flera lärandeforskare med olika teoretisk inriktning. Enligt Ausubel sker meningsfullt lärande när ny information kopplas till tidigare kunskaper (1968). Dewey (1938/1997) hävdar att vi hela tiden transformeras av våra erfarenheter, och våra erfarenheter transformeras i sin tur av vår tidigare erfarenhet. Detta utgör Deweys kontinuitetsprincip, vilken innebär att "every experience both takes up something from those which have gone before and modifies in some way the quality of those which come after" (ibid s 35).

Fokus för denna artikel ligger på hur enskilda lärande skapar mening utifrån de resurser i form av termer och visuella representationer som de har tillgång till och erfarenheter av. Det lärande som studeras har en social liksom en individuell aspekt. Den mening som skapas i intervjuerna beror av den lärandes tidigare erfarenheter, kunskaper och språkliga resurser, liksom på själva intervjusituationen och samspelet med intervjuaren. 


\section{Betydelsen av metaforer för meningsskapande}

När den lärande möter nya vetenskapliga begrepp är det enda sättet att skapa mening att jämföra dessa med tidigare kända begrepp, erfarenheter och det språk som den lärande förfogar över, såväl vetenskapligt språkbruk som vardagsspråk. Språket är det främsta mediet för vår förmåga till abstraktion. Att använda sig av metaforer och analogier kan härvid vara ett sätt att koppla någonting okänt till någonting redan bekant. För att förenkla framställningen kommer jag här att använda beteckningen "metaforer" för att beteckna alla typer av metaforer, analogier och liknelser.

Lakoff och Johnson (1980) har argumenterat för att metaforer har en central betydelse för vårt sätt att uppfatta och förstå vår omvärld. Detta är särskilt tydligt när det gäller lärande av abstrakta begrepp som, enligt Lakoff och Johnson, endast kan läras indirekt. Vårt sätt att förstå världen tar alltid sin utgångspunkt i vår kroppsliga existens och vår grundläggande fysiska erfarenhet av världen (Lakoff, 1987; Lakoff \& Johnson, 1999). Däremot hävdar Murphy (1996) att de begrepp som vi försöker att förstå genom att använda en metafor förstås som separata, självständiga begrepp, även om de antar en liknande struktur. Således menar vi, enligt Murphy, högst olika saker när vi talar om en sten i naturen och när vi metaforiskt talar om att "hans hjärta är av sten". Detta hindrar dock inte Lakoff och Johnson från att ha rätt i sin uppfattning att metaforiska uttryck är viktiga för hur vi skapar och förstår abstrakta begrepp. Metaforer är inte bara viktiga som pedagogiska verktyg, utan utgör också begreppsliga verktyg för vår förståelse av naturen (Hesse, 1963). Många vetenskapliga begrepp har ett metaforiskt ursprung; inom cell- och molekylärbiologi kan man nämna sådana vanliga begrepp som "budbärarRNA", "DNA-kedja", "cell", "kärna" etc.

Även om användning av metaforer i den naturvetenskapliga undervisningen utförligt har diskuterats i den ämnesdidaktiska litteraturen (Duit, 1991), har diskussionen i hög grad utgått från läraroch läromedelsperspektivet. Hur de lärande själva relaterar olika fenomen till varandra genom att använda metaforer har studerats i mindre utsträckning, även om det finns undantag (Bloom 1992a, 1992b; Cameron, 2002; Heywood, 2002).

Det finns dock problem kopplade till användning av metaforer. Metaforer kan tolkas alltför bokstavligt och kan leda in i ofruktbara resonemang. Eleverna och läraren kan ha olika uppfattningar om vad som är de väsentliga aspekterna av en metafor. Sutton (1995) påpekar att metaforer många gånger kan förvirra snarare än underlätta förståelse. Bloom (1992a, 1992b) påpekar dock att vi som lärare bör vara uppmärksamma på elevernas sätt att tala och att kreativt använda metaforer. Betydelsen av barns spontana metaforer för deras meningsskapande är framträdande också i de studier som utförts av Jakobson och Wickman (2005).

Cameron påpekar att metaforiska uttryck även kan utgöras av verb. Hon ger exempel på hur barn använder sig av verbmetaforer för att skapa mening i sin naturvetenskapliga undervisning. Hon betonar att barns spontana begrepp är en viktig utgångspunkt för utveckling av vetenskapliga begrepp (2002). Att använda ett verb som betecknar välkända processer och handlingar kan således vara ett sätt för eleverna att närma sig det vetenskapliga innehållet.

\section{Lärande och tillägnande}

Gee (2002) gör en distinktion mellan att lära sig och att tillägna sig något. Med lärande avses en medveten, reflekterande process, medan tillägnande avser en till större del omedveten socialiseringsprocess. Tillägnande sker framför allt genom att man iakttar, härmar och prövar. Detta är centralt exempelvis i en mästare-lärling-relation, där större delen av den kunskap som överförs aldrig uttrycks i ord, utan är "tyst". Enligt Gee måste tillägnande (åtminstone till del) föregå lärande. I ett klassrum där tillägnande och lärande inte balanseras på ett rimligt sätt priviligeras vanligen de elever vars tillägnandeprocess redan startat utanför skolan. 
Att lära sig att använda ett naturvetenskapligt språk innebär inte enbart att medvetet lära sig betydelsen av olika termer, utan är en mycket mer komplex process, som i hög utsträckning bygger på det som Gee kallar tillägnande. Det är inte nog att veta definitionen av ett begrepp och vad termen refererar till, utan man måste också förstå hur begreppet används, i vilka sammanhang det används och hur det sammanhänger med andra begrepp, något man framför allt lär sig genom att iaktta och samverka med någon som behärskar området. Det är först då som begreppen kan bli meningsfulla för den lärande.

\section{Ett semiotiskt perspektiv på meningsskapande}

Semiotik har av de Saussure karaktäriserats som studiet av tecknens liv i samhället. Den semiotiska forskningens objekt är tecken, som inkluderar såväl form/betecknande som mening/betecknat. Särskiljandet av form/betecknande och mening/betecknat i den lingvistiska traditionen från de Saussure har av Ausubel (1968) formulerats som en separation mellan begreppsord och begrepp. Kress (2003) menar att semiotik skiljer sig från lingvistik genom att fokusera på form och mening snarare än enbart form. Han hävdar att den teckenskapande processen inte ska ses som slumpartad och tillfällig. Det tecken (betecknande) som används för att uttrycka ett visst innehåll (betecknat) väljs inte slumpvis, utan bör ses som det mest adekvata tillgängliga uttrycket för detta innehåll. Den kreativa teckenskapande processen bör, enligt Kress, sättas i fokus. Mening och den form den uttrycks i hänger samman (2003).

Anward (1994) hävdar att olika verksamheter, som exempelvis molekylärgenetik och litteraturvetenskap, använder sig av olika semiotiska koder för sin verksamhet. Den grundläggande semiotiska koden, anchoring code, för de molekylära livsvetenskaperna bygger i högre grad på visuell information än litteraturvetenskap, som i högre grad bygger på talad och skriven information. När information som uttrycks i en visuell kod, exempelvis om DNA-molekylens struktur, översätts till ord går med nödvändighet information förlorad. Trots detta är det nödvändigt att översätta den grundläggande semiotiska koden till en tolkande kod, interpretative code.

\section{MULTIMODALT LÄRANDE}

Kress med flera betonar att mening kan uttryckas genom flera olika modaliteter (tal, skrift, gester, visuellt, taktilt etc) och inte enbart genom språklig kommunikation. De understryker därför vikten av att inta ett multimodalt perspektiv på lärande (Kress, Jewitt, Ogborn \& Tsatsarelis, 2001).

Roth har tillsammans med sina medarbetare konstruerat ett multimodalt synsätt på hur lärande av vetenskapliga begrepp sker. Han hävdar att det finns kontinuitet och progression i lärandet mellan fysisk manipulation av objekt, gester, deiktiska (utpekande) uttryck och mer abstrakta, talade och skrivna, språkliga uttryck. Kontextbundna uttryck som gester och deiktiska uttryck är, enligt Roth et al, i hög grad meningsfulla i lärandesituationen (Roth, 2001; Roth \& Lawless, 2002).

Goodwin $(1995,1996)$ har likaså utifrån ett multimodalt perspektiv studerat hur professionella inom olika yrkesområden (exempelvis oceanografer och arkeologer) skapar mening med hjälp av olika semiotiska resurser. Hans undersökningar visar att gester och deiktiska uttryck i hög grad kommer till användning i den vetenskapliga verksamheten. Goodwin framhåller mångfalden och komplexiteten i hur ämnesmässig kunskap uttrycks, exempelvis genom tolkning av grafer, utpekande av färg på olika jordlager etc.

\section{Det visuella språket inom de molekylära livsvetenskaperna}

De molekylära livsvetenskaperna studerar objekt och processer som är oåtkomliga för direkt sinneserfarenhet och som därför endast kan studeras indirekt, genom olika former av modellering. Dessa modeller uttrycks vanligen i form av visuella representationer. För att kunna lära sig molekylärbiologi behöver man således inte bara kunna utföra praktiska, laborativa moment och an- 
vända relevanta texter - man behöver också kunna förstå den speciella form av bildspråk som används inom de molekylära livsvetenskaperna.

Kozma et al har studerat hur noviser och experter konstruerar mening utifrån visuella representationer inom kemi. Enligt Kozma är förmågan att kunna använda sig av flera olika representationsformer och kunna växla mellan dessa ett tecken på expertkunskap (Kozma, 2003; Kozma, Chin, Russell \& Marx, 2000; Kozma \& Russell, 2005).

Denna studie syftar till att undersöka hur nybörjare inom de molekylära livsvetenskaperna skapar mening med hjälp av visuella representationer och vilka språkliga resurser de använder för att skapa mening. Det innehåll som uttrycks i dessa är framställningar av proteiners struktur och funktion. Föreliggande artikel fokuserar det verbala språk som eleverna använder sig av för att skapa mening kring ett naturvetenskapligt innehåll som i grunden bygger på en visuell anchoring code.

\section{Metoder}

I den empiriska undersökning som utgör grunden för denna artikel studeras gymnasieelevers tolkningar av en uppsättning visuella representationer av proteiners struktur och funktion. Semistrukturerade intervjuer (Kvale, 1997) genomfördes med totalt 20 gymnasieelever på gymnasiets naturvetenskapliga, natur/samhällsvetenskapliga och naturhumanistiska program. Två av dessa elever intervjuades tillsammans vid ett tillfälle, detta för att inför fortsatta intervjuer på grundläggande universitetsnivå pröva parintervju som metod. Fem av eleverna gick naturhumanistiskt program på en friskola, övriga elever gick på ett kommunalt gymnasium, alla i en medelstor svensk stad. Eleverna valdes utifrån en strävan att få en jämn fördelning mellan hög- medel- och lågpresterande elever (utgående från betyg i naturvetenskapliga ämnen) från de elever som anmält sig frivilliga att intervjuas. På grund av att ett begränsat antal elever anmälde sig som frivilliga, kom andelen högpresterande elever att överväga. Under intervjuerna, som pågick ca 40 minuter, fick eleverna resonera utifrån samma urval av visuella representationer av proteiner och proteiners funktion, vilka utgjordes av omarbetade exempel från elevernas egna läroböcker i kemi och biologi. Eleverna ombads att tolka de visuella representationerna utifrån sina förkunskaper. Intervjuerna spelades in på minidisk och transkriberades ordagrant. En besläktad metod att studera studenters sätt att resonera kring molekylärbiologiska representationer har använts av bl a Schönborn, Anderson och Grayson (2002). Transkripten analyserades med avseende på vilka språkliga resurser (vetenskapliga termer, metaforer etc) som eleverna använder för att skapa mening kring de visuella representationerna. En färgkodning genomfördes av elevernas uttalanden, varvid metaforer från undervisningen, spontana metaforer, verbmetaforer och hjälpord (se nedan) markerades. I nästa steg relaterades de färgkodade orden till intervjusammanhanget och det gjordes en bedömning huruvida de bildade en ämnesmässigt meningsfull förklaring eller ej. För en mer omfattande metodbeskrivning se Rundgren (2006).

\section{RESULTAT}

Innan eleverna har omvandlat naturvetenskapliga termer som "budbärarRNA" och "ribosom" till begrepp som de kan använda i egna förklaringar, ersätter de inte sällan vetenskapliga termer med andra ord. Som ersättning för de vetenskapliga begreppsorden använder de deiktiska uttryck som "den där", eller också metaforer, som de i vissa fall fått från sin undervisning och i andra fall skapar själva, d v s spontana metaforer. Dessutom använder de en ouppmärksammad grupp av ord som saknar tydlig denotation (i ordets språkvetenskapliga betydelse (se Löbner, 2002)), sådana som "flärp", "flopp" och "plupp". För denna kategori av ord föreslås här beteckningen hjälpord. 
Nedan ges exempel på hur eleverna använder metaforer och hjälpord för att förklara för intervjuaren (CJ) vad de visusella representationerna avbildar. Eleverna har i verkligheten andra namn än de som här anges. I det första exemplet blir Maria (M), ombedd att tolka en bild av ett cellmembran, i vilket olika kanalprotein är synliga. Som ersättning för begreppet "receptor" använder hon metaforen "flagga":

CJ: Kan du berätta vad är det som händer här?

M: Ja, jag vet att själva proteinet... det släpps in ämnen och ut ämnen som cellen behöver för olika transporter och uppbyggnad av olika saker, det som händer är väl att det ämnet som finns utanför, det drar till sig, det har dom ju sådana här flaggor för att känna igen vilket ämne det var. Jag kommer inte ihåg vad de hette... det var nåt med flaggor i alla fall.

CJ: Okej.

M: ...som kännetecknar vilka ämnen som fanns och vilka som skulle tas in sen så öppnades själva proteinet som en kanal och tog in det och sen stängdes den för att inget mer kunde komma in, sen släppte det ut när det skulle ut transporter.

CJ: Dom här... flaggor, som du sa, är det något som sitter på de molekyler som ska in?

M: Nej, det sitter väl på själva cellväggen, jag kommer inte ihåg. Det var... vad hette dom? I alla fall, jag kommer inte på det, men de sitter utanpå cellen så att säga och känner av vilka ämnen som finns och vilka som den ska dra till sig och vilka den ska släppa ut och så ser de till det. Och själva proteinet gör ju som... är som en pump som släpper ut och in ämnen, ser till att det inte kommer in för mycket eller för lite och öppnas och stängs.

I det andra fallet visas Erika (E) en visuell representation av proteinsyntesen. För att beskriva konformationsförändringen hos DNA vid början av transkriptionen associerar hon metaforiskt till ett garnnystan. I slutet av citatet ersätter hon termen "kvävebaser" med hjälpordet "floppar":

CJ: Känner du igen den här bilden?... Du vet vad den föreställer?

E: Ja.. Det är väl DNA, vad ska vi säga... transkription och sånt...

CJ: Ja, just det... Och nu skulle jag vilja be dig berätta vad som händer. Om vi börjar här i kärnan, med DNA, vad händer här, först?

E: Eh... nu måste jag kolla lite... Först är den väl som ett nystan och sen vecklar den sig upp, tror jag.

CJ: Du menar DNA:t?

E: Ja, DNA:t....

$[\ldots]$

E: Det här kodar för aminosyror som... alltså, vad blir det... tre stycken såna där, alltså floppar [skrattar till] blir en aminosyra. Och dom här aminosyrorna sätts ihop till en lång kedja av ett protein.

I det tredje fallet visas Kajsa $(\mathrm{K})$ samma visuella representation och förklarar en transportRNAmolekyl (tRNA) med kvävebaser på följande vis. I stället för termen "kvävebaser" använder hon hjälpordet "pluppar":

K: Alltså det är ju en slags kedja med dom här små... plupparna som mRNA:t kan känna igen å fästa på rätt ställe, så det proteinet hamnar på rätt ställe så att det kan... svetsas samman med det bredvid som är en annan slags kod eller vad man ska säga... så att...

CJ: Ja... Det är en annan slags kod? På vilket sätt är den annan...? Kan du utveckla det?

K: Alltså varje sån här som aminosyran fäster vid har en speciell kod eller vad man ska kalla det... [CJ:Mm] som är specifikt för den aminosyran...

I det fjärde fallet tillfrågas Jonas (J) om han kan frammana ett protein för sin inre syn. Han associerar metaforiskt till en hopsnurrad boll: 
CJ: Om du tänker dig ett protein, får du en bild framför dig i huvudet?

$\mathrm{J}$ : Ja, det får jag nog. Det är nog nån bild vi har visat på biologin, en boll, eller vad man ska kalla det, som är helt hopsnurrad med strängar av aminosyror.

Denna metafor återkommer senare under intervjun då han blir visad en visuell representation av veckning av ett protein:

CJ: Just det. Och vad är det här du ser, på varse sida?

J: Alltså, det är ju en hopsnurrad boll på ena sidan och en icke hopsnurrad... sträng eller snöre eller någonting på andra.

Vid ett tillfälle intervjuades två elever, Ulla (U) och Berit (B) samtidigt, vilket gav upphov till en diskussion där flera metaforiska uttryck kom till användning. Här visas samma visuella representation av proteinsyntesen som tidigare och intervjuaren frågar efter molekyler av ribosomalt RNA (rRNA) som går ut ur kärnmembranet. Ulla använder metaforen "lok" för att beskriva rRNAmolekylerna. Berit använder ett hjälpord, "plufsa", för att beteckna processen i vilken rRNA som producerats i cellkärnan tränger ur kärnmembranet och ut i cytoplasman:

U: Det ser ut som massa lok eller nåt...

B: Det ser ju ut som här...vänta... där kommer den där... Här kommer ju liksom lösa... DNA-kedjor ser det ut som... här... liksom... den här [U:Mm] Frågan är varför å vad det är för nånting.

CJ: Är det DNA som går ut?

B: Nä, jag har ingen aning. Det ser ju så ut.

CJ: Titta på pilen här... vart går dom?

B: Är det delar?

CJ: Delar av vad då?

B: Ja, det är underdel å överdel... [skrattar]

$\mathrm{U}$ : Jaha, är det ribosomer?

B: Som plufsar ut... Men jag trodde att dom typ byggdes ihop av typ proteiner, fast det trodde jag inte gjordes här...

I intervjumaterialet används metaforer och hjälpord av eleverna för att beskriva olika molekylära strukturer och processer. Vissa metaforer kommer från deras undervisning (från lärare och läroböcker), medan andra troligen är spontana. Hjälpord används av en fjärdedel av eleverna $\mathrm{i}$ intervjuerna. Majoriteten av dessa använder hjälpord endast vid ett tillfälle under intervjun. En elev använde dock samma hjälpord, "plupp", vid inte mindre än fyra tillfällen för att beteckna olika strukturer. I samtliga fall då hjälpordet "plupp" yttras används det för att beteckna små, kompakta strukturer.

En av eleverna i exemplet ovan, Erika, använder sig av ett annat hjälpord, "flopparna", för att beteckna kvävebaser på en tRNA-molekyl. Samma struktur betecknas av Kajsa som "pluppar". Hjälporden "flopp" och "plupp" tycks således ha delvis överlappande konnotationer. Såväl Erika som Kajsa använder hjälpord inom ramen för ett resonemang som visar att de har en förståelse för vad den genetiska koden innebär och hur genetisk information överförs mellan DNA, RNA och proteiner. Däremot har de svårt att komma ihåg termen "kvävebaser". Det är möjligen intressant att notera att Erika i exemplet ovan skrattar till när hon använder hjälpordet "flopparna", vilket kan tolkas som att hon vanligen använder hjälporden i mer informella samtalssammanhang än intervjusituationen.

Metaforer används i högre utsträckning än hjälpord i intervjuerna. Alla elever i undersökningen använder sig någon gång under intervjun av metaforiska uttryck. De metaforer som förekommer i exemplet ovan är: 
Erika: Ett nystan och sen vecklar den sig upp, vilket beskriver konformationsförändringen av DNA:t vid starten av transkriptionen. Förutom den metaforiska kopplingen till ett garnnystan använder Erika ett verb, veckla upp, som associerar till vardagliga händelser.

Jonas: En hopsnurrad boll, en metafor som han använder dels för att beskriva sin inre bild av ett protein och dels för att beskriva den visuella representationen av veckning av ett protein. Att metaforen och hans beskrivning av den uttrycks vid två tillfällen under intervjun visar att den har en viss konstans, och att den är knuten till något centralt i Jonas föreställningar kring proteiner. Man kan också lägga märke till att tillägget "hopsnurrad" gör metaforen mer avancerad och till en bättre beskrivning av tredimensionell rymdstruktur hos ett protein än den enkla metaforen "en boll", som enbart associerar till en rund form.

Ulla: Lok, med vilken hon karaktäriserar formen på ribosomalt RNA. På den bild som användes under intervjuerna har dessa representerats som rundade former med några uppstickande strukturer som möjligen skulle kunna leda tankarna till skorstenen och förarhytten på ett ånglok. Det verkar inte som att Ulla förbinder denna association till ånglok med några egenskaper hos rRNA. Denna spontana metafor verkar, liksom i flera andra fall, enbart vara kopplad till det betecknandes form.

Maria: Flagga, med vilken hon beskriver en struktur som skjuter ut från cellmembranet (som hon av misstag kallar cellvägg). Ur hennes resonemang kan man utläsa att hon använder metaforen "flagga" för att beteckna begreppet receptor. När jag senare bad henne att förklara vad hon menat med "flagga" kunde jag bekräfta att hon verkligen avsåg receptor, även om hennes uppfattning om receptorbegreppet tycktes vara något vag. Hon kunde erinra sig att hon fått metaforen "flagga" från ett visst kursavsnitt, men hon kunde inte säkert minnas om det var hon själv, hennes kamrater eller läraren som kommit på metaforen. I flera fall under intervjuerna visar eleverna en tydligt urskiljbar naturvetenskaplig förståelse i sina resonemang, trots att de inte använder vetenskapliga termer.

\section{Diskussion}

Ett begreppsord kan anta olika betydelser i olika kontexter. Detta förhållande betecknas inom språkvetenskap med termen polysemi (Löbner, 2002). Det är således naturligt att ett begreppsord som introduceras i undervisningen ger upphov till andra associationer hos eleverna än hos läraren, beroende på skillnader i erfarenhetsbakgrund och språk. Läraren, som tillhör en kommunikativ praktik, till vilken eleverna ännu inte har tillgång, kan lätt tala förbi eleverna. Men eleverna kan också tala förbi läraren. Läraren kan vara så inskolad i den ämnesmässiga tolkningen av ett ord, att hon eller han missar de betydelser som eleverna tilldelar begreppsorden. Likaså kan det i vissa fall vara svårt för läraren att uppmärksamma att begreppsförståelse kan kläs i ord som kommer från andra språkliga kontexter än den ämnesmässiga.

\section{Användning av metaforer och tillägnandet av ett abstrakt sätt att resonera}

Metaforer utgör inte enbart ett slags poetisk utsmyckning eller förenklande bilder som kan hjälpa den oinvigde att förstå vetenskapligt innehåll. Metaforer används för att göra abstrakta begrepp hanterbara, av såväl vetenskapssamhället som nybörjare på området.

Inom vetenskapen används metaforer i kunskapsformering, för att klä nya idéer om naturens beskaffenhet (många gånger uttryckta i en matematisk eller visuell anchoring code) i en mer tillgänglig språkdräkt (interpretative code). Metaforer kan bli så inarbetade i vårt tal att vi glömmer deras metaforiska ursprung. En polypeptidkedja är ingen kedja utan aminosyremolekyler bundna till varandra med peptidbindningar. Vi märker knappt den underliggande metaforen "kedja" (se även Figur 1). 
För den som är på väg in i den naturvetenskapliga kulturen används metaforer som en del i kunskapstillägnelse, $\mathrm{d}$ v s processen då ett nytt innehåll och ett nytt sätt att använda språk kopplas till tidigare begrepp, erfarenheter och språk. Slutsatserna från denna - förvisso begränsade - undersökning indikerar att gymnasieelevernas sätt att resonera kring visuella representationer i hög grad präglas av användning av termer från vardagslivet. Resonemang kring exempelvis kemiska bindningar och elektrostatiska krafter lyser med sin frånvaro i intervjumaterialet. Med utgångspunkt från Lakoff och Johnsons $(1980,1999)$ resonemang tolkar jag den rikliga förekomsten av vardagliga och erfarenhetsmässigt konkreta beskrivningar av molekylära processer med ord som hoppa, binda, släppa, klippa, veckla upp etc i intervjuerna som en indikation på att abstrakta begrepp först tillägnas inom ramen för ett konkret resonemang med kopplingar till vardagliga erfarenheter och först sedan, efter fortsatt naturvetenskaplig verksamhet, får den abstrakta karaktär som vi förbinder med naturvetenskapligt tänkande och språkbruk. Som ett exempel på detta konkreta sätt att resonera kan jag citera Marias beskrivning av hur ett enzym fungerar: "... sen har du ett ämne som det ska bryta ner eller påskynda å bryta ner så binder det väl fast runt det och klipper isär det i mindre delar..." Marias sätt att resonera avviker ifrån det som traditionellt betraktas som det naturvetenskapliga idiomet. Samtidigt är det uppenbart att hon har förstått någonting väsentligt om enzymer, något som kan fungera som en språngbräda för en djupare förståelse av ämnet och tillägnandet av ett mer elaborerat naturvetenskapligt språk. En möjlig förklaring till att eleverna använder dessa konkreta verb kan vara att dessa används av deras lärare för att på ett lättillgängligt sätt förklara abstrakta processer och att de helt enkelt tar efter lärarens sätt att resonera. Fortsatta studier kan påvisa huruvida elevernas konkreta sätt att resonera framför allt härrör från deras eget sätt att bearbeta stoffet eller om detta sätt att resonera främst härrör från deras undervisning.

Gymnasieelevers användning av hjälpord, spontana metaforer och verbmetaforer hämtade från vardagliga situationer utgör naturliga inslag i deras kunskapsutveckling. Om det finns en progression av den lärandes resonemang från det konkreta till det abstrakta (se även Roths argumentering i Roth, 2001 och Roth \& Lawless, 2002) bör vi inte heller förvänta oss att eleverna redan från början ska ha förmågan att resonera abstrakt när ämnesområdet är nytt för dem. Detta är en förmåga som tillägnas gradvis. Därmed inte sagt att läraren inte bör använda sig av abstrakta termer och att eleverna inte behöver träna på att använda abstrakta termer som t ex diffusion - tvärtom! Elevernas användning av hjälpord och metaforer kan ge läraren en nyckel till att förstå vilka meningar elever lägger kring vetenskapliga begrepp, samtidigt som deras mångtydighet naturligtvis kan skapa tolkningsproblem. Denna undersökning tyder emellertid på att ett icke-vetenskapligt språkbruk kan uttrycka en förståelse som kan utgöra en början till en djupare naturvetenskaplig förståelse och ett naturvetenskapligt språk.

\section{Ett protein kan i olika kontexter betecknas som:}

$\begin{array}{lllll}\text { En kedja av aminosyror } & \text { Ett pärlhalsband } & \text { En hopsnurrad boll } & \text { En flärp } & \text { Den där } \\ \text { Metaforer amvända } & \text { Metaforer använda } & \text { Spontana } & \text { Hjälpord } & \text { Deiktiska } \\ \text { av vetenskapssamhället } & \text { i undervisningen } & \text { metaforer } & & \text { uttryck }\end{array}$

Figur 1. Förslag till modell som visar kontinuiteten mellan metaforer, hjälpord och utpekande (deiktiska) uttryck. I denna modell betraktas hjälpord som ett slags vaga metaforer. Metaforer använda av vetenskapssamhället diskuteras $i$ bl a Sutton (1995), metaforer använda $i$ undervisningen i t ex Duit (1991), spontana metaforer i Bloom (1992b), deiktiska uttryck $i$ Roth (2001) och hjälpord i denna studie. 


\section{Ett försök att karaktärisera hjälpord}

Hjälpord kan tolkas som metaforer med vag mening. Deras mening är, i likhet med deiktiska uttryck, alltid kontextuellt betingad. Hjälpord kan definieras som ord utan tydlig denotation, vilka används som ersättning för termer som i normalfallet används inom ett ämnesspecifikt språkbruk. Eftersom de molekylära livsvetenskaperna i hög utsträckning använder sig av en visuell semiotisk kod som anchoring code (Anward, 1994), är det möjligt att ha en viss förståelse för denna förankrade kod, samtidigt som man saknar förmåga att uttrycka denna i en tolkande kod. Hjälpord fungerar som en avsiktligt vag namngivning och karaktäristik av ett objekt eller en process, för vilken den talande inte tycker sig ha någon användbar benämning. Vagheten är ett centralt drag i hjälpordens karaktär och bör, liksom fallet är med deiktiska uttryck, uppfattas som mångtydighet snarare än brist på precision. Hjälpord väljs inte slumpvis, utan det valda hjälpordet ger en viss tolkning, och möjligen också värdering, av objektet. Ett objekt som namnges som en "flärp" kan aldrig vara en "plupp". En "flärp" konnoterar, enligt mina erfarenheter, någonting avlångt och rörligt, som vidhäftar en större struktur (exempel: en mRNA-molekyl på väg ut ur cellkärnan). En "plupp", avser däremot små, kompakta, ofta diffusa former.

I anslutning till Kress' (2003) uppfattning, att det tecken som väljs bör betraktas som det mest adekvata tillgängliga uttrycket, menar jag att hjälpord är adekvata uttryck för det den lärande vill uttrycka i en viss situation. Funktionen hos hjälpord är att de hjälper till att skapa en mening som annars inte skulle kunna formuleras och jag föreslår därför beteckningen "hjälpord". I Figur 1 föreslår jag en modell för hur hjälpord kan ses som en övergång mellan metaforer och deiktiska uttryck.

Hjälpord kan sägas utgöra ett slags alternativ namngivning. Detta medför att de vanligen ersätter namn på objekt, men de kan också ersätta namn på händelser och processer. Hjälpord kan således ersätta, inte enbart substantiv, utan också ord från andra ordklasser, främst verb. En av eleverna i undersökningen, Berit, förklarade processen i vilken ribosomalt RNA tränger ur kärnmembranet med orden "som plufsar ut". Verbet "plufsa" konnoterar en oformlig massa som rör sig ut ur någonting. Eftersom ordet saknar tydlig denotation, trots att det med utgångspunkt från dess användning och böjning uppenbarligen är ett verb, och ersätter ett verb som vanligen skulle användas som beskrivning av denna process, bör det betraktas som ett hjälpord. Genom använda detta hjälpord i denna situation uttrycker hon en tolkning av rRNA som en oformlig massa som hastigt tränger ut ur kärnan. Hjälpordet "plufsa" ger också en antydan om att hjälpord många gånger tycks ha ett onomatopoetiskt (ljudhärmande) ursprung. Det är möjligt att många hjälpord har uppstått ur en association mellan grafiska representationer och elektroniska ljud (tänk på ord som "plupp" och "blipp").

Användningen av hjälpord tycks variera mellan olika individer. Vissa använder dem relativt frekvent medan andra inte tycks använda några hjälpord alls. Enligt denna undersökning verkar det inte finnas någon koppling mellan användning av hjälpord och studieresultat. Hjälpord och spontana metaforer används av såväl högpresterande elever som elever med lägre betyg. Men eftersom majoriteten av de elever som intervjuades var högpresterande, är det för tidigt att uttala sig om huruvida detta gäller generellt. Ytterligare undersökningar av användning av hjälpord skulle möjligen kunna ge en annan bild.

Undersökningen ger en viss antydan om att hjälpord används i högre grad i mer informella sammanhang, mellan elev och elev, än i intervjusituationen. Därför kan studier av gruppdiskussioner komma att ge mer information om användningen av hjälpord än individuella intervjuer. Att hjälpord ändå förekommer i intervjuerna - vilket i sig är ett intressant resultat - kan bero på att hjälpordens vaga karaktär gör det möjligt att ge en förklaring utan att använda sig av en vetenskaplig term som man känner sig osäker på. Hjälporden har dessutom fördelen framför metaforer att de, på grund av sin vaghet, gör tolkningen mer öppen och mångtydig. Det är troligt att hjälpord 
och metaforer är extra frekventa vid lärande i de molekylära livsvetenskaperna, eftersom ämnet i hög grad bygger på tolkning av visuella representationer av abstrakta, för sinnena oåtkomliga, fenomen.

I anslutning till bland andra Roths resonemang (Roth, 2001; Roth \& Lawless, 2002) om hur kontextbundna uttryck som gester och deiktiska uttryck kan vara en del av meningsskapandet hävdar jag sammanfattningsvis, utifrån mitt empiriska material, att dessa till synes meningslösa hjälpord blir meningsbärande i lärandesituationer där eleven försöker föra ett naturvetenskapligt resonemang men saknar den korrekta terminologin. Hjälpord fungerar utpekande, och urskiljande och i viss mån beskrivande. De utgör ett verktyg för att skapa sammanhang och mening.

\section{Betydelsen av hjälpord och spontana metaforer för lärande}

Resultatet från denna undersökning antyder att elever kan uttrycka en naturvetenskaplig förståelse på ett ickevetenskapligt språk. Ur ett multimodalt perspektiv på meningsskapande och språktillägnande innebär ämneskunskaper mycket mer än kunskaper om betydelsen av olika termer. Genom att använda gester, deiktiska uttryck och hjälpord kan elever i ett lärandesammanhang uttrycka en mening som går långt utöver det till synes enkla tecknet. Även bakom till synes meningslösa ord som "floppar" visar sig ligga en viss förståelse av kvävebasernas roll i den genetiska koden. Och metaforen "flagga" visar sig avslöja en viss förståelse för molekylär signalering. Resultaten i denna studie tycks tyda på att hjälporden vanligen uttrycker just en viss förståelse för innehållet, en förståelse som är på väg mot större fullständighet. Användningen av hjälpord utgör en teckenskapande akt, ett försök att skapa förståelse och mening. Hjälpord används av nybörjare som ett medel att tillägna sig ett ämnesspecifikt språk, och bör inte blandas samman med yrkesmässig slang eller jargong. Det senare bygger på en hög grad av förtrogenhet med ämnesspråket och utgör en helt annan språklig företeelse än hjälpord, trots att ytliga likheter kan förekomma mellan hjälpord och t ex de hänsyftningar och förkortningar som förekommer i vardagssamtal mellan yrkeskollegor.

Det är möjligt att det är just ur de till synes "ickevetenskapliga" förklaringar som elevernas spontana metaforer och hjälpord utgör som vi som lärare kan hämta djupare förståelse för hur elever tänker kring det innehåll de stöter på i undervisningen. Dessa kan avslöja mer om elevers tänkande än ett "korrekt" ämnesmässigt språkbruk. Faktum är att användande av korrekta, abstrakta termer många gånger visar sig dölja utantillinlärning och ytförståelse, vilket visats av den omfattande forskningen om elevers alternativa föreställningar och begrepp (se bl a Pfundt \& Duit, 1994). Om vi tar dessa resultat ad notam är detta snarast normaltillståndet för naturvetenskaplig undervisning. Sannolikt gör förhållandet att skolan i hög grad formas av bedömning att undervisningen drivs mot former som gör en kvantitativ bedömning av elevernas kunskaper lättare (Gee, 2003). Detta kan i sin tur leda till att eleverna bedöms utifrån sin förmåga att använda korrekta begreppsord snarare än sin kreativa förmåga att skapa mening. Denna undersökning tyder på att vi i så fall missar någonting viktigt.

\section{TACK}

Författaren vill tacka Mari Stadig Degerman och Martin Eriksson för hjälp med elevintervjuerna, liksom även Lena Tibell och Jan Anward för värdefulla synpunkter. Denna studie har finansierats av Svenska Vetenskapsrådet (anslag 2003-4275), Norrköpings kommun och Nationella Forskarskolan i Naturvetenskapernas och Teknikens Didaktik. 


\section{REFERENSER}

Anward, J. 1994. Semiotics in Educational Research. I International Encyclopedia of Educational Research (Vol. 9, s. 5411-5417): Pergamon Press.

Ausubel, D. 1968. Educational psychology - a cognitive view. New York: Holt, Rinehart and Winston INC.

Bakhtin, M. M. 1986. Speech Genres and Other Late Essays. Austin: University of Texas Press.

Bernstein, B. 1964. Elaborated and Restricted Codes: Their Social Origins and some Consequences. I J. J. Gumperz \& D. Hymes (Red.), American Anthropologist (Vol. 66, s. 55-69).

Bloom, J. W. 1992a. Contexts of Meaning and Conceptual Integration: How Children Understand and Learn. I R. A. Duschl \& R. J. Hamilton (Red.), Philosophy of science, cognitive psychology, and educational theory and practice. Albany: State University of New York Press.

Bloom, J. W. 1992b. The development of scientific knowledge in elementary school children: A context of meaning perspective. Science Education, 76 (4), 339-413.

Cameron, L. 2002. Metaphors in the Learning of Science: a discourse focus. British Educational Research Journal, 28 (5), 673-688.

Dewey, J. 1938/1997. Experience and Education. New York: Touchstone.

Duit, R. 1991. On the role of analogies and metaphors in learning science. Science Education, 75 (6), 649-672.

Gee, J. P. 2002. Social Linguistics and Literacies: Ideology in Discourses (andra utgåvan). London: Routledge/Falmer.

Gee, J. P. 2003. Opportunity to Learn: a language-based perspective on assessment. Assessment in Education, 10 (1), 27-46.

Gee, J. P. 2004. Situated Language and Learning. A critique of traditional schooling. New York: Routledge.

Goodwin, C. 1995. Seeing in depth. Social Studies of Science, 25, 237-274.

Goodwin, C. 1996. Practices of Color Classification. Ninchi Kagaku. Cognitive Studies: Bulletin of the Japanese Cognitive Science Society, 3 (2), 62-82.

Hesse, M. 1963. Models and Analogies in Science. London: Sheed \& Ward.

Heywood, D. 2002. The Place of Analogies in Science Education. Cambridge Journal of Education, 32 (2), 233-247.

Jakobson, B. \& Wickman, P-O. 2005. Transformation through language use - childrens' spontaneous metaphors in primary science. Manuskript, Institutionen för undervisningsprocesser, kommunikation och lärande, Lärarhögskolan, Stockholm.

Kozma, R. 2003. The material features of multiple representations and their cognitive and social affordances for science understanding. Learning and Instruction, 13, 205-226.

Kozma, R., Chin, E., Russell, J. \& Marx, N. 2000. The Roles of Representations and Tools in the Chemistry Laboratory and Their Implications for Chemistry Learning. The Journal of the Learning Sciences, 9 (2), 105-143.

Kozma, R. \& Russell, J. 2005. Students becoming chemists: developing representational competence. I J. K. Gilbert (Red.) Visualization in Science Education (s. 121-146) Dordrecht: Springer.

Kress, G. 2003 Literacy in the New Media Age. New York: Routledge.

Kress, G., Jewett, C., Ogborn, J. \& Tsatsarelis, C. 2001. Multimodal Teaching and Learning: The Rhetorics of the Science Classroom. London: Continuum.

Kvale, S. 1997. Den kvalitativa forskningsintervjun. Lund: Studentlitteratur.

Lakoff, G. 1987. Women, Fire and Dangerous Things: What Categories Reveal about the Mind. Chicago: University of Chicago Press.

Lakoff, G. \& Johnson, M. 1980. Metaphors we live by. Chicago: University of Chicago Press.

Lakoff, G. \& Johnson, M. 1999. Philosophy in the Flesh. The Embodied Mind and Its Challenge to Western Thought. New York: Basic Books.

Lemke, J. L. 1990. Talking science: language, learning and values. Norwood, New Yersey: Ablex publishing corporation.

Löbner, S. 2002. Understanding semantics. New York: Oxford University Press. 


\section{Carl-Johan Rundgren}

Mortimer, E. F. \& Scott, P. H. 2003. Meaning Making in Secondary Science Classrooms. Philadelphia: Open University Press.

Ogborn, J., Kress, G., Martins, I. \& McGillicuddy, K. 1996. Explaining Science in the Classroom. Buckingham: Open University Press.

Pfundt, H. \& Duit, R. 1994. Bibliography: Students' Alternative Frameworks and Science Education (fjärde utgåvan). Kiel: IPN.

Rivard, L. P. \& Straw, S. B. 2000. The Effect of Talk and Writing on Learning Science: An Explorative Study. Science Education 84 (5), 566-593.

Roth, W-M. 2001 From action to discourse: The bridging function of gestures. Cognitive Systems Research, 3, 535-554.

Roth, W-M. \& Lawless, D. 2002. Scientific investigations, metaphorical gestures, and the emergence of abstract scientific concepts. Learning and Instruction, 12, 285-304.

Rundgren, C-J. 2006 Meaning-Making in Molecular Life Science Education - upper secondary school students' interpretation of visualizations of proteins. Licentiatavhandling, Institutionen för samhälls- och välfärdsstudier, Linköpings universitet, Linköping.

Schönborn, K. J., Anderson, T. R. \& Grayson, D. J. 2002. Student Difficulties with the Interpretation of a Textbook Diagram of Immunoglobulin G (IgG). Biochemistry and Molecular Biology Education, 30 (2), 93-97.

Sutton, C. 1995. Words, science and learning. Buckningham: Open University Press. 